\title{
PENERAPAN FUZZY AHP UNTUK PENINGKATAN KETEPATAN DAN EFEKTIVITAS PENILAIAN KINERJA KARYAWAN
}

\author{
Wiji Setiyaningsih 1) , Amak Yunus Eko Prasetyo ${ }^{2)}$ \\ 1) Sistem Informasi Universitas Kanjuruhan \\ 2) Teknik Informatika Universitas Kanjuruhan \\ E-mail: wiji@unikama.ac.id ${ }^{1)}$, amakyunus@unikama.ac.id ${ }^{2)}$
}

\begin{abstract}
Abstraksi
Pada PT. Kimora Surabaya penilaian kinerja karyawan dari 15 cabang menggunakan 14 kriteria berdasarkan posisi pada divisinya oleh setiap pimpinan divisi. Kriteria yang digunakan lebih cenderung pada penilaian yang bersifat subyektif. Penilaian dilakukan dengan pengisian form angket penilaian yang diisi oleh setiap pimpinan divisi, berikutnya pihak HRD mengkalkulasi secara manual hingga didapatkan prosentase akhir. Proses penilaian tersebut dilakukan sekitar satu bulan, dan biasanya mengalami pengunduran waktu. Ketidaktepatan dalam penilaian kinerja karyawan berdampak pada hasil akhir yang kurang tepat, sehingga menimbulkan kecemburuan sosial, komplain pada HRD, serta semakin meningkatnya karyawan yang resign. Untuk mengatasi hal tersebut diterapkan metode fuzzy AHP. Dari hasil penelitian dan uji coba didapatkan dengan penerapan fuzzy AHP maka penilaian kinerja karyawan ketepatan penentuan hasil akhir meningkat, dan efektivitas proses penilaiannya juga meningkat.
\end{abstract}

Kata Kunci : Penilaian Kinerja, Ketepatan, Efektivitas, Fuzzy AHP

\begin{abstract}
At PT. Kimora Surabaya employee performance appraisal of 15 branches using 14 criteria based on position in division by each division leader. The criteria used are more likely to be subjective judgments. Assessment is done by filling the assessment questionnaire form filled by each division leader, next the HRD calculate manually to get the final percentage. The assessment process takes about a month, and usually retards time. Inappropriateness in employee performance appraisal results in a less precise outcome, resulting in social jealousy, complaints on HRD, and an increasingly resigned employee. To overcome this applied AHP fuzzy method. From the results of research and trials obtained with the application of AHP fuzzy then the employee performance appraisal accuracy determination of the final results increased, and the effectiveness of the assessment process also increased
\end{abstract}

Keywords: Performance Assessment, Accuracy, Effectiveness, Fuzzy AHP

\section{Pendahuluan}

Penilaian kinerja merupakan proses dalam organisasi yang bertujuan mengevaluasi pelaksanaan kerja masing-masing personal. Pada penilaian kinerja dapat dilakukan penilaian terhadap kontribusi karyawan kepada organisasi dalam periode waktu tertentu. Umpan balik kinerja memungkinkan karyawan mengetahui seberapa baik karyawan bekerja apabila dibandingkan dengan standar-standar organisasi.

Seperti halnya PT. Kimora Surabaya untuk jenjang karier karyawan dilakukan penilaian kinerja karyawan setiap tahun, dan pemberian reward dilakukan pemilihan karyawan terbaik dalam target waktu project tertentu. Selama ini penilaian kinerja karyawan dilakukan dengan memperhatikan 14 kriteria berdasarkan posisi pada divisinya oleh setiap pimpinan divisi. Dari 14 kriteria tersebut lebih banyak kriteria kualitatif yang bersifat subyektif dibanding dengan kriteria kuantitatif yang bersifat obyektif. Secara teknis penilaian kinerja karyawan dilakukan dengan pengisian form angket penilaian yang diisi oleh setiap pimpinan divisi, berikutnya pihak HRD mengkalkulasi secara manual dengan menjumlah point seluruh kriteria dan dibagi dengan banyaknya kriteria, 
sehingga didapatkan prosentase akhir. Proses penilaian hingga didapatkan hasil akhir tersebut dilakukan kurang lebih membutuhkan waktu

satu bulan, dan biasanya mengalami pengunduran waktu karena juga harus menilai karyawan dari 15 cabang.

Dari hasil wawancara dengan pihak HRD, dalam proses penilaian tersebut permasalahan yang sering muncul yaitu pada ketidaktepatan pimpinan divisi dalam memberikan penilaian kepada karyawan karena yang dinilai adalah subjektifitas setiap karyawan dari 14 kriteria tersebut. Dengan demikian penilaian yang diberikan bersifat tidak pasti (bersifat fuzzy = kabur atau tidak jelas). Ketidaktepatan dalam memberikan penilaian terhadap kinerja karyawan berdampak pada hasil keputusan akhir yang diberikan kurang tepat, yang menimbulkan kecemburuan sosial, komplain pada HRD, serta semakin meningkatnya karyawan yang resign.

Permasalahan di atas dapat diperbaiki dengan membangun suatu Sistem Pendukung Keputusan (SPK) dengan menerapkan metode perankingan. Pada kasus pemilihan karyawan terbaik ini terdapat sifat subjektifnya lebih banyak.

Bidang IT terdapat metode yang mampu mengatasi paparan permasalahan tersebut di atas, yaitu Analytichal Hierarchy Process (AHP) seperti riset yang telah dilakukan oleh Wiji dan Yusriel (2014) tentang penilaian kinerja tenaga pendidik dan tenaga edukatif menggunakan AHP, dengan hasil penilaian kinerja tenaga pendidik dan tenaga edukatif sebagai pendukung penentuan kenaikan gaji, yang tidak hanya atas dasar unsur subyektifitas saja, namun juga penilaian yang obyektif, meskipun tetap menggunakan pedoman DP3 menjadi lebih efektif, optimal, dan tepat sasaran.

Akan tetapi pada kenyataannya metode AHP belum mampu mengatasi permasalahan yang samar atau tidak pasti [11]. Menurut Kabir dan Hasin (2011) AHP mengalami kesulitan dalam menangani penilaian ketidakpastian dan yang bersifat subjektif. Oleh karena itu, salah satu varian AHP yaitu Fuzzy AHP digunakan untuk

mengatasi ketidakmampuan AHP dalam menangani variabel linguistik. Dalam prosedur Fuzzy AHP, cara pendekatan yang dilakukan adalah dengan melakukan fuzzifikasi pada skala AHP sehingga diperoleh skala baru yang disebut skala fuzzy AHP [14]. Terdapat pula riset Norhikmah, dkk (2013) yang membandingkan metode fuzzy AHP dengan AHP dalam penerapan system pendukung keputusan yang membuktikan bahwa metode AHP dapat digunakan dalam menangani criteria kualitatif dan kuantitatif, namun fuzzy AHP lebih baik dalam mendeskripsikan keputusan yang samar dan hasilnya lebih akurat untuk ketepatannya. Riset Ahmad Faisol, dkk (2014) tentang komparasi fuzzy AHP dengan AHP pada sistem pendukung keputusan investasi property juga membuktikan bahwa fuzzy AHP memiliki keunggulan lebih cepat pada saat proses pembobotan alternatif dan tingkat akurasi yang lebih tinggi dalam hal ketepatan hasil akhir dibandingkan dengan AHP. Muhammad Eka (2013) yang membuktikan riset analisa penggunanaan metode AHP dengan fuzzy AHP yaitu fuzzy AHP hanya bisa digunakan untuk kriteria-kriteria yang nilai kepastiannya belum terlihat sedangkan metode AHP untuk kriteria yang sudah bernilai pasti. Berikutnya terdapat riset Ardianto, dkk (2014) tentang kombinasi fuzzy dengan AHP, yaitu sistem pendukung keputusan untuk penilaian kinerja pegawai pada Rumah Sakit Onkologi Surabaya, dengan fuzzy AHP mampu menghasilkan urutan ranking yang sama dengan perhitungan manual, sehingga valid. Fuzzy AHP juga mampu menentukan ranking prioritas ketika terdapat nilai pegawai yang jumlahnya sama. Berikutnya penilaian kinerja karyawan juga dapat dilakukan dengan cepat.

Berdasarkan uraian masalah dan beberapa referensi riset sebelumnya, maka dilakukan penerapan metode fuzzy AHP yang bertujuan untuk meningkatkan ketepatan dan efektivitas penilaian kinerja karyawan.

\section{Tinjauan Pustaka}

Multi Criteria Decision Making (MCDM) merupakan suatu metode pengambilan keputusan untuk menetapkan alternatif terbaik dari sejumlah alternatif berdasarkan beberapa kriteria yang akan menjadi bahan pertimbangan. Salah satu metode MCDM adalah metode Fuzzy Analytic Hierarchy Process (FAHP). Dalam AHP untuk pengambilan keputusan dengan banyak kriteria yang bersifat subjektif, seringkali seorang pengambil keputusan dihadapkan pada suatu permasalahan yang sulit dalam penentuan bobot setiap kriteria, sehingga Metode Fuzzy AHP digunakan untuk menangani kelemahan pada metode AHP. Metode pendukung FAHP menitikberatkan pada fuzzifikasi nilai pada matriks perbandingan 
berpasangan yang sebelumnya berupa bilangan klasik pada AHP. Fuzzy AHP memungkinkan deskripsi proses pembuatan keputusan lebih akurat dan menggambarkan secara matematis spesifik ketidakpastian. FAHP dianggap lebih baik dalam mendeskripsikan keputusan yang samar-samar serta meminimalisasi ketidakpastian dalam skala AHP yang berbentuk nilai 'crisp' dimana suatu elemen pada suatu himpunan hanya memiliki 2 kemungkinan keanggotaan.

F-AHP merupakan gabungan metode AHP dengan pendekatan konsep fuzzy. F-AHP menutupi kelemahan yang terdapat pada AHP, yaitu permasalahan terhadap kriteria yang memiliki sifat subjektif lebih banyak.

Ketidakpastian bilangan direpresentasikan dengan urutan skala. Untuk menentukan derajat keanggotaan pada F-AHP, digunakan aturan fungsi dalam bentuk bilangan fuzzy segitiga atau Triangular Fuzzy Number (TFN) yang disusun berdasarkan himpunan linguistik. Jadi, bilangan pada tingkat intensitas kepentingan pada AHP ditransformasikan ke dalam himpunan skala TFN [2].

Terdapat beberapa riset yang diteliti oleh beberapa ahli dalam berbagai bidang diantaranya: riset Igon, dkk (2014) tentang Perancangan Sistem Pendukung Keputusan dengan Metode Fuzzy AHP dalam Penyeleksian Pemberian Kredit, Jasril (2011) tentang sistem pendukung keputusan pemilihan karyawan terbaik menggunakan metode fuzzy AHP, Marischa dan Rahmadsyah (2014) tentang analisis metode fuzzy AHP dalam menentukan promosi jabatan, Adnyana, dkk (2016) tentang penerapan metode fuzzy AHP dalam penentuan sektor yang berpengaruh terhadap perekonomian propinsi Bali, Iskandar, dkk (2013) tentang sistem pendukung keputusan seleksi beasiswa PPA dan BBM menggunakan metode fuzzy AHP.

Chang (1996) dikutip oleh Iis Afrianty (2011) mendefinisikan nilai intensitas AHP ke dalam skala fuzzy segitiga yaitu membagi tiap himpunan fuzzy dengan 2, kecuali untuk intensitas kepentingan 1. Skala fuzzy segitiga yang digunakan Chang dapat dilihat pada tabel 1 berikut.

Tabel 1. Skala Nilai Fuzzy Segitiga

\begin{tabular}{|c|c|c|c|}
\hline $\begin{array}{c}\text { Intensitas } \\
\text { Kepentingan } \\
\text { AHP }\end{array}$ & Himuguman Linguistil & $\begin{array}{l}\text { Triangular } \\
\text { Fuesy Numbror } \\
\text { (IRN) }\end{array}$ & $\begin{array}{l}\text { Reciprocal } \\
\text { (Kebalikan) }\end{array}$ \\
\hline 1 & $\begin{array}{l}\text { Perbendingan elemen yang sama (Just } \\
\text { Equai) }\end{array}$ & $(1,1,1)$ & $(1,1,1)$ \\
\hline 2 & Pertengahan (Intemediate) & $(1 / 2,1,3 / 2)$ & $(2 / 3,1,2)$ \\
\hline 3 & $\begin{array}{l}\text { Elemen samu culup penting dan yang } \\
\text { laimayla (moderatey important) }\end{array}$ & $(1,3 / 2,2)$ & $(1 / 2,2 / 3,1)$ \\
\hline 4 & $\begin{array}{l}\text { Pertengahan (Intermediate) elemen sau } \\
\text { lebilh culvup penting dari yang lainnya) }\end{array}$ & $(3 / 2,2,5 / 2)$ & $(2 / 5,1 / 2,2 / 3)$ \\
\hline 5 & $\begin{array}{l}\text { Elemen sant kuat pentinguya dan yang lain } \\
\text { (Strongyy Imporant) }\end{array}$ & $(2,5 / 2,3)$ & $(1 / 3,2 / 5,1 / 2)$ \\
\hline 6 & Pertengahan (Intermediate) & $(5 / 2,3,7 / 2)$ & $(2 / 7,1 / 3,2 / 5)$ \\
\hline 7 & $\begin{array}{l}\text { Elemen sant lebih luat pentingnya dari } \\
\text { yang lain (Vøy Srrong) }\end{array}$ & $(3,7 / 2,4)$ & $(1 / 4,2 / 7,1 / 3)$ \\
\hline 8 & Pertengahan (Intemmediate) & $(7 / 2,4,9 / 2)$ & $(2 / 9,1 / 4,27)$ \\
\hline 9 & $\begin{array}{l}\text { Elemen satu mutlak lebih penting dari yang } \\
\text { lainmya (Extremely Strong) }\end{array}$ & $(4,9 / 2,9 / 2)$ & $(2 / 9,2 / 9,1 / 4)$ \\
\hline
\end{tabular}

Adapun langkah dari fuzzy AHP adalah sebagai berikut [15] [12] [8] [10]:

a. Membuat struktur hirarki masalah yang akan diselesaikan dan menentukan perbandingan matriks berpasangan antar kriteria dengan skala TFN.

b. Menentukan nilai sintesis fuzzy

(Si) prioritas dengan rumus:

$$
S i=\sum_{j=1}^{m} M_{j} \times \frac{1}{\sum_{i=1}^{n} \sum_{j=1}^{m} M_{i}^{j}} \ldots \ldots \ldots \text { (1) }
$$

\section{Dimana:}

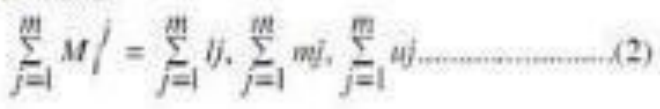

\section{Sedangkan}

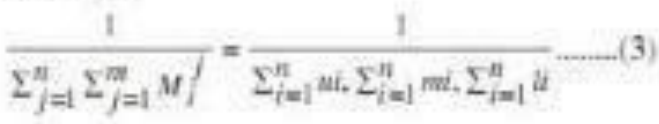

c. Menentukan Nilai Vektor (V) dan Nilai Ordinat Defuzzifikasi (d').

Jika hasil yang diperoleh pada setiap matrik fuzzy, M2 >= M1 $(\mathrm{M} 2=(12, \mathrm{~m} 2, \mathrm{u} 2)$ dan $\mathrm{M} 2=(11, \mathrm{~m} 1, \mathrm{u} 1)$ maka nilai vektor dapat dirumuskan sebagai berikut :

\section{$V(M \geq \geq M 1)=\sup \left[\min \left(\mu M 1(x), \min \left(\mu M_{2}(y)\right)\right)\right]$}

Atau sama dengan grafik pada gambar berikut :

$$
\text { if } w: \geq n t,
$$

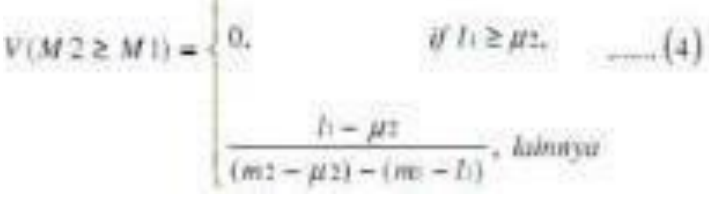


Jika hasil nilai fuzzy lebih besar dari $\mathrm{k}$, Mi $(\mathrm{i}=1,2, \mathrm{k})$ maka nilai vector dapat didefinisikan sebagai berikut :

$V\left(M \geq M_{1}, M_{2} \ldots \ldots, M\right)=V(M \geq M i) d a n$

$V(M \geq M 2) \operatorname{dan} . V(M \geq M i)=\min V\left(M \geq M_{i}\right),(5)$

Asumsikan bahwa,

$d^{\prime}(A i)=\min V(S i \geq S k)$

Untuk $k=1,2, \ldots, n: k \neq i$, maka diperoleh

nilai bobot vector

$$
W^{\prime}=\left(d^{\prime}\left(A_{1}\right), d^{\prime}\left(A_{2}\right), \ldots, d^{\prime}\left(A_{N}\right)\right)^{\mathbf{T}} \text {. }
$$

Dimana $\mathrm{Ai}=1,2, \ldots ., \mathrm{n}$ adalah $\mathrm{n}$ element keputusan.

d. Normalisasi nilai bobot vektor fuzzy (W) Setelah dilakukan normalisasi dari persamaan

(7) maka nilai bobot vector yang ternormalisasi adalah seperti rumus berikut

$$
W=\left(d\left(A_{1}\right), d\left(A_{2}\right), \ldots, d\left(A_{v}\right)\right)^{\mathbf{T}}
$$

Dimana $\mathrm{W}$ adalah bilangan non fuzzy.

\section{Metode Penelitian}

Dalam penelitian ini menggunakan tahapan penelitian sebagai berikut:

\section{a. Studi Pendahuluan}

Studi pendahuluan merupakan awal dari penelitian, bertujuan untuk mendapatkan masukan yang diperlukan sehingga dapat menjadi acuan pembuatan dasar aplikasi yang lebih baik. Hal ini dilakukan dengan kegiatan membaca literatur-literatur yang berkaitan dengan permasalahan yang sedang diteliti, yaitu sistem penilaian kinerja karyawan, dan metode fuzzy AHP.

\section{b. Identifikasi Masalah}

Identifikasi masalah dilakukan melalui proses wawancara dan observasi langsung ke obyek penelitian, berikutnya juga dilakukan studi kepustakaan. Wawancara yaitu proses memperoleh keterangan untuk tujuan penelitian dengan cara tanya jawab dengan pimpinan dan bagian HRD PT. Kimora Surabaya yang berkaitan dengan permasalahan yang sedang diteliti yaitu penilaian kinerja karyawan.

\section{c. Penetapan Tujuan}

Tujuan dari penelitian ini yaitu menerapkan metode fuzzy AHP dalam peningkatan ketepatan dan efektivitas penilaian kinerja karyawan.

\section{d. Pengumpulan Data}

Pengumpulan data merupakan tahap pengambilan data atau sampel yang berhubungan dengan permasalahan yang sedang dibahas, akan dibuat rancangan sistem informasinya dan selanjutnya dibuat aplikasi sistem pendukung keputusan penilaian kinerja karyawan dengan penerapan fuzzy AHP.

\section{e. Perancangan Sistem Pendukung} Keputusan penilaian Kinerja Karyawan

Dalam tahap perancangan ini akan menggambarkan alur proses berjalannya sistem penilaian kinerja karyawan mulai dari perancangan Data Flow Diagram (DFD), Entity

Relationship Diagram (ERD), dan Flowchart.

Tahapan ini telah tertuang dalam prosiding

Seminar Nasional UNIKAMA 2017 Wiji

Setiyaningsih dan Amak Yunus dengan judul makalah Konsep Perancangan Sistem Pendukung Keputusan Kinerja Karyawan pada PT. Kimora Surabaya Berbasis Web.

\section{f. Pembuatan Aplikasi}

Pembuatan aplikasi sistem pendukung keputusan penilaian kinerja karyawan dengan penerapan fuzzy AHP menggunakan Macromedia Dreamweaver 8 sebagai pendukung untuk pembuatan tampilan aplikasi, database MySQL dan bahasa PHP sebagai program instruksi proses.

\section{g. Implementasi Sistem dan Pengujian \\ Implementasi sistem baru yaitu proses}

penerapan dan pengujian aplikasi sistem pendukung keputusan penilaian kinerja karyawan dengan penerapan fuzzy AHP berbasis web pada PT. Kimora Surabaya.

\section{Hasil dan Pembahasan}

Dalam penelitian ini menggunakan data penilaian kinerja karyawan tahun 2016, yang dilakukan penilaian oleh setiap pimpinan divisi. Adapun kriteria yang digunakan dalam penilaian kinerja karyawan meliputi 14 kriteria yaitu: tanggung jawab (k1), berani menanggung resiko (k2), memiliki tujuan realistis (k3), memiliki rencana kerja $(\mathrm{k} 4)$, memanfaatkan umpan balik (k5), perilaku menolong (k6), toleransi (k7), loyalitas (k8), taat pada aturan (k9), motivasi diri (k10), komitmen (k11), pengembangan diri (k12), kedisiplinan (k13), serta sanksi (k14).

Pada tahun 2016 menggunakan nilai tingkat kepentingan kriteria dari rentang nilai skala 1-9 sebagai berikut:

Tabel 2. Nilai Tingkat Kepentingan

Antar Kriteria

\begin{tabular}{|c|c|c|c|c|c|c|}
\hline $\mathrm{K} 1$ & $\mathrm{~K} 2$ & $\mathrm{~K} 3$ & $\mathrm{~K} 4$ & $\mathrm{~K} 5$ & $\mathrm{~K} 6$ & $\mathrm{~K} 7$ \\
\hline 5 & 9 & 4 & 3 & 5 & 6 & 7 \\
\hline $\mathrm{K} 8$ & $\mathrm{~K} 9$ & $\mathrm{~K} 10$ & $\mathrm{~K} 11$ & $\mathrm{~K} 12$ & $\mathrm{~K} 13$ & $\mathrm{~K} 14$ \\
\hline 1 & 1 & 8 & 2 & 6 & 3 & 9 \\
\hline \multicolumn{7}{c}{ Dari nilai tingkat kepentingan antar }
\end{tabular}

kriteria tersebut, berikutnya dilakukan 
perbandingan antar kriteria dengan sifat metode AHP yaitu reciprocal dengan hasil sebagai berikut:

Tabel 3. Perbandingan Antar Kriteria dengan AHP

\begin{tabular}{|c|c|c|c|c|c|c|}
\hline & $\mathbf{K} 1$ & $\mathbf{K} 2$ & $\mathbf{K} 3$ & $\mathbf{K} 4$ & $\mathbf{K 5}$ & $\mathbf{K 6}$ \\
\hline $\mathbf{K} 1$ & $\mathbf{1}$ & 0.2 & 2 & 3 & 1 & 0.5 \\
\hline $\mathbf{K} \mathbf{2}$ & 5 & $\mathbf{1}$ & 6 & 7 & 5 & 4 \\
\hline $\mathbf{K} 3$ & 0.5 & 0.16667 & $\mathbf{1}$ & 2 & 0.5 & 0.33333 \\
\hline $\mathbf{K} 4$ & 0.33333 & 0.14286 & 0.5 & $\mathbf{1}$ & 0.33333 & 0.25 \\
\hline $\mathbf{K} 5$ & 1 & 0.2 & 2 & 3 & $\mathbf{1}$ & 0.5 \\
\hline $\mathbf{K} 6$ & 2 & 0.25 & 3 & 4 & 2 & $\mathbf{1}$ \\
\hline $\mathbf{K} 7$ & 3 & 0.33333 & 4 & 5 & 3 & 2 \\
\hline $\mathbf{K} 8$ & 0.2 & 0.11111 & 0.25 & 0.33333 & 0.33333 & 0.16667 \\
\hline $\mathbf{K}$ 9 & 0.2 & 0.1111 & 0.25 & 0.33333 & 0.33333 & 0.16667 \\
\hline $\mathbf{K} 10$ & 4 & 0.5 & 5 & 6 & 4 & 3 \\
\hline $\mathbf{K} 11$ & 0.25 & 0.125 & 0.33333 & 0.5 & 0.25 & 0.2 \\
\hline $\mathbf{K} 12$ & 2 & 0.25 & 3 & 4 & 2 & 1 \\
\hline $\mathbf{K} 13$ & 0.33333 & 0.14286 & 0.5 & 1 & 0.33333 & 0.25 \\
\hline $\mathbf{K} 14$ & 5 & 1 & 6 & 7 & 5 & 4 \\
\hline
\end{tabular}

\begin{tabular}{|c|c|c|c|c|c|c|c|}
\hline $\mathbf{K 7}$ & $\mathbf{K 8}$ & $\mathbf{K 9}$ & $\mathbf{K 1 0}$ & $\mathbf{K 1 1}$ & $\mathbf{K 1 2}$ & $\mathbf{K 1 3}$ & $\mathbf{K 1 4}$ \\
\hline 0.33333 & & 5 & 0.25 & 4 & 0.5 & 3 & 0.2 \\
\hline 3 & & 9 & 2 & 8 & 4 & 7 & 1 \\
\hline 0.25 & & 4 & 0.2 & 3 & 0.33333 & 2 & 0.16667 \\
\hline 0.2 & & 3 & 0.16667 & 2 & 0.25 & 1 & 0.14286 \\
\hline 0.33333 & & 3 & 0.25 & 4 & 0.5 & 3 & 0.2 \\
\hline 0.5 & & 6 & 0.33333 & 5 & 1 & 4 & 0.25 \\
\hline 1 & & 7 & 0.5 & 6 & 2 & 5 & 0.33333 \\
\hline 0.14286 & 1 & 1 & 0.125 & 0.5 & 2 & 5 & 0.11111 \\
\hline 0.14286 & & $\mathbf{1}$ & 0.125 & 0.5 & 0.16667 & 0.33333 & 0.11111 \\
\hline 2 & & 8 & 1 & 7 & 0.33333 & 0.16667 & 0.5 \\
\hline 0.16667 & & 2 & 0.14286 & 1 & 0.2 & 0.5 & 0.125 \\
\hline 0.5 & 0.5 & 6 & 3 & 5 & 1 & 4 & 0.25 \\
\hline 0.2 & 0.2 & 3 & 6 & 2 & 0.25 & 1 & 0.14286 \\
\hline 3 & & 9 & 2 & 8 & 4 & 7 & 1 \\
\hline
\end{tabular}

Selanjutnya nilai tersebut dikonversi menggunakan skala fuzzy sesuai tabel 1, sebagai berikut:

Tabel 4. Mengkonversi Skala AHP ke Skala Fuzzy Setiap Kriteria

\begin{tabular}{|c|c|c|c|c|c|c|}
\hline \multirow{2}{*}{ Kri te ri a } & \multicolumn{3}{|c|}{ K1 } & \multicolumn{3}{|c|}{ K2 } \\
\hline & $\mathbf{L}$ & M & $\mathbf{U}$ & $\mathbf{L}$ & M & $\mathbf{U}$ \\
\hline K1 & 1 & 1 & 1 & 0.33333 & 0.4 & 0.5 \\
\hline K2 & 2 & 2.5 & 3 & 1 & 1 & 1 \\
\hline K3 & 0.66667 & 1 & 2 & 0.28571 & \begin{tabular}{|l|}
0.33333 \\
\end{tabular} & 0.4 \\
\hline K4 & 0.5 & 0.66667 & 1 & 0.25 & 0.28571 & 0.33333 \\
\hline K5 & 1 & 1 & 1 & 0.33333 & 0.4 & 0.5 \\
\hline K6 & 0.5 & 1 & 1.5 & 0.4 & 0.5 & 0.66667 \\
\hline K7 & 1 & 1.5 & 2 & 0.5 & 0.66667 & 1 \\
\hline K8 & 0.33333 & 0.4 & 0.5 & 0.22222 & 0.22222 & 0.25 \\
\hline K9 & 0.33333 & 0.4 & 0.5 & 0.22222 & 0.22222 & 0.25 \\
\hline K10 & 1.5 & 2 & 2.5 & 0.66667 & 1 & 2 \\
\hline K11 & 0.4 & 0.5 & 0.66667 & 0.22222 & 0.25 & 0.28571 \\
\hline K12 & 0.5 & 1 & 1.5 & 0.4 & 0.5 & \begin{tabular}{|l}
0.66667 \\
\end{tabular} \\
\hline K13 & 0.5 & \begin{tabular}{|l|}
0.66667 \\
\end{tabular} & 1 & 0.25 & 0.28571 & 0.33333 \\
\hline K14 & 2 & 2.5 & 3 & 1 & 1 & 1 \\
\hline
\end{tabular}

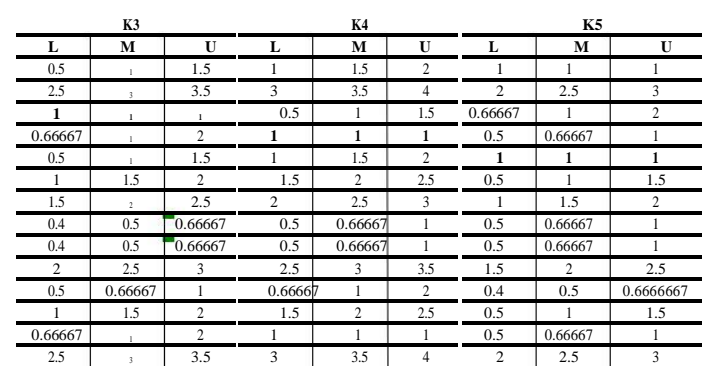

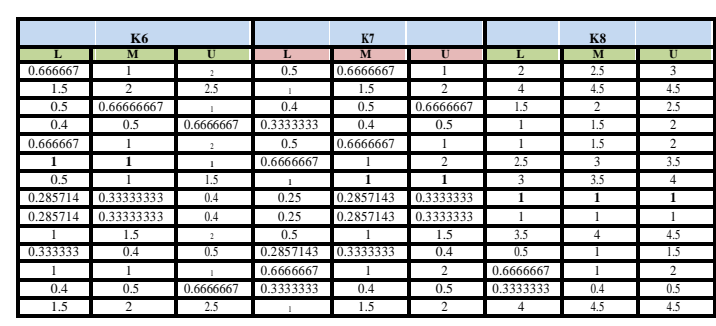
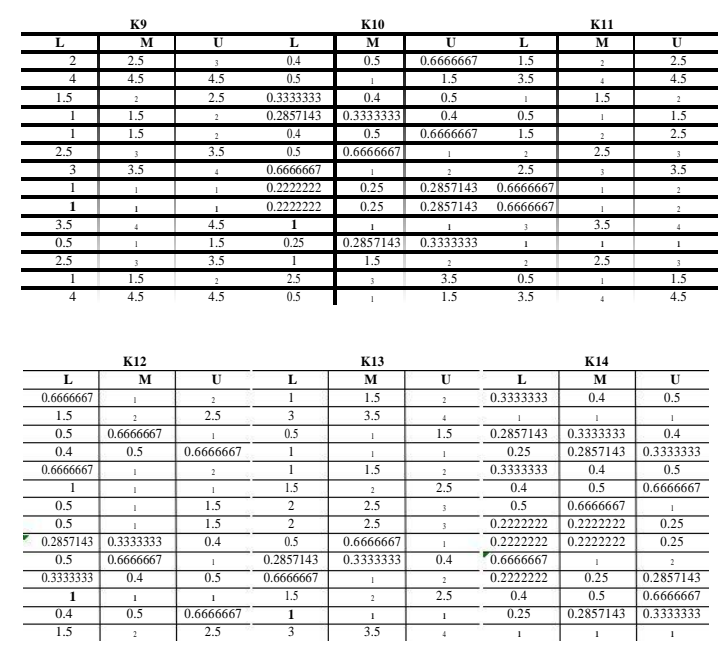

Setelah didapatkan nilai tersebut di atas, maka setiap baris dijumlahkan, berikutnya hasil jumlah baris digunakan mencari nilai jumlah kolom, yang dapat digunakan untuk menghitung nilai sintesis fuzzy (Si) sebagai berikut: 
Tabel 5. Nilai Sintesis Fuzzy (Si) Kriteria

\begin{tabular}{|c|c|c|c|}
\hline \multirow{2}{*}{ Kri te ri a } & \multicolumn{3}{|c|}{$\mathbf{S} \mathbf{i}$} \\
\hline & $\mathbf{L}$ & $\mathbf{M}$ & $\mathbf{U}$ \\
\hline K1 & $0.039 \varnothing$ & 0.0651 & 70.06283 \\
\hline $\mathrm{K} 2$ & 0.0923 & 0.1401 & 90.14855 \\
\hline K3 & 0.029 & 0.0514 & 70.04694 \\
\hline K4 & 0.0244 & 0.0408 & 60.03938 \\
\hline K5 & $0.033 \phi$ & 0.0574 & 90.05309 \\
\hline K6 & 0.0483 & 0.0793 & 80.07777 \\
\hline K7 & 0.0595 & 0.097 & 30.09579 \\
\hline K8 & 0.0245 & 0.0385 & 90.03946 \\
\hline K9 & 0.0193 & 0.0289 & 90.03111 \\
\hline K10 & 0.0669 & 0.1056 & 20.10773 \\
\hline K11 & $0.019 \varnothing$ & 0.0329 & 80.03059 \\
\hline K12 & 0.0443 & 0.074 & 90.07127 \\
\hline K13 & 0.029 & 0.0468 & 80.04692 \\
\hline K14 & 0.0923 & 0.1401 & 90.14855 \\
\hline
\end{tabular}

Dari hasil tersebut di atas, dilakukan perhitungan nilai vektor fuzzy AHP (v) dan nilai ordinat defuzzifikasi (d') hingga didapatkan nilai bobot vektor fuzzy (W') sebagai berikut:

Tabel 6. Bobot Vektor Fuzzy (W') Kriteria

\begin{tabular}{|l|c|c|c|c|r|r|}
\hline $\mathrm{W}^{\prime}=$ & 0 & 0 & 0.0006 & 0.0029 & 0 & 0 \\
\hline & $\mathrm{k} 1$ & $\mathrm{k} 2$ & $\mathrm{k} 3$ & $\mathrm{k} 4$ & $\mathrm{k} 5$ & $\mathrm{k} 6$ \\
\hline
\end{tabular}

\begin{tabular}{|c|c|c|c|c|c|c|c|}
\hline 0 & 0.32096 & 1 & 0.02033 & 0.24962 & 0 & 0.24962 & 0 \\
\hline $\mathrm{k} 7$ & $\mathrm{k} 8$ & $\mathrm{k} 9$ & $\mathrm{k} 10$ & $\mathrm{k} 11$ & $\mathrm{k} 12$ & $\mathrm{k} 13$ & $\mathrm{k} 14$ \\
\hline
\end{tabular}

Nilai W' untuk seluruh kriteria dijumlahkan sebagai pembagi nilai $\mathrm{W}^{\prime}$ dari setiap kriteria untuk mendapatkan nilai normalisasi nilai bobot vektor fuzzy (W) yang merupakan nilai prioritas kriteria sebagai berikut:

Tabel 7. Prioritas Kriteria

\begin{tabular}{|l|r|r|r|r|r|r|}
\hline $\mathrm{W}=$ & 0 & 0 & 0.0003 & 0.0015 & 0 & 0 \\
\hline & $\mathrm{k} 1$ & $\mathrm{k} 2$ & $\mathrm{k} 3$ & $\mathrm{k} 4$ & $\mathrm{k} 5$ & $\mathrm{k} 6$ \\
\hline
\end{tabular}

\begin{tabular}{|r|c|c|c|c|c|c|r|}
\hline 0 & 0.17405 & 0.54227 & 0.01102 & 0.13536 & 0 & 0.1353 & 0 \\
\hline $\mathrm{k} 7$ & $\mathrm{k} 8$ & $\mathrm{k} 9$ & $\mathrm{k} 10$ & $\mathrm{k} 11$ & $\mathrm{k} 12$ & $\mathrm{k} 13$ & $\mathrm{k} 14$ \\
\hline
\end{tabular}

Setelah didapatkan nilai prioritas

kriteria, berikutnya yaitu melakukan perbandingan antar alternatif berdasarkan setiap kriteria dimulai dari k1 sampai dengan k14.

Tabel 8. Nilai Alternatif dari K1

\begin{tabular}{|c|c|}
\hline ID KYW & NILAI K1 \\
\hline A & 9 \\
\hline B & 8 \\
\hline C & 8 \\
\hline
\end{tabular}

Dengan proses yang sama dengan perbandingan kriteria, maka langkah berikutnya yaitu dilakukan perbandingan antar alternatif berdasarkan K1 dengan sifat metode AHP yaitu reciprocal dengan hasil sebagai berikut:

\begin{tabular}{|c|c|c|c|}
\multicolumn{5}{|c}{ Alternatif dari K1 } \\
\hline K1 & A & B & C \\
\hline A & $\mathbf{1}$ & 2 & 2 \\
\hline B & 0.5 & $\mathbf{1}$ & 1 \\
\hline C & 0.5 & 1 & $\mathbf{1}$ \\
\hline
\end{tabular}

Selanjutnya nilai tersebut dikonversi menggunakan skala fuzzy sesuai tabel 8, sebagai berikut:

Tabel 10. Mengkonversi Skala AHP ke Skala Fuzzy Setiap Alternatif dari K1

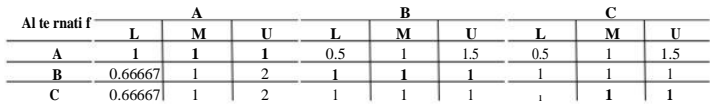

Setelah didapatkan nilai tersebut di atas, maka setiap baris dijumlahkan, berikutnya hasil jumlah baris digunakan mencari nilai jumlah kolom, yang dapat digunakan untuk menghitung nilai sintesis fuzzy (Si) sebagai berikut:

Tabel 11. Nilai Sintesis Fuzzy (Si) Alternatif dari K1

\begin{tabular}{|c|c|c|c|}
\hline \multirow{2}{*}{ Al te rnati $f$} & \multicolumn{3}{|c|}{$\mathbf{S i}$} \\
\hline & $\mathbf{L}$ & M & $\mathbf{U}$ \\
\hline $\mathbf{A}$ & 0.16667 & $\begin{array}{lll}33333 & 0.5 \\
\end{array}$ & 4545 \\
\hline B & 0.222220 & 333330.54 & 545 \\
\hline $\mathrm{C} 0.222$ & 20.33333 & .54545 & \\
\hline
\end{tabular}

Dari hasil tersebut di atas, dilakukan perhitungan nilai vektor fuzzy AHP (v) dan nilai ordinat defuzzifikasi (d') hingga didapatkan nilai bobot vektor fuzzy (W') sebagai berikut:

Tabel 12. Bobot Vektor Fuzzy (W') Alternatif dari K1

\begin{tabular}{|l|l|l|l|}
\hline $\mathrm{W}^{\prime}=$ & 1 & 1 & 1 \\
\hline & $\mathrm{A}$ & $\mathrm{B}$ & $\mathrm{C}$ \\
\hline
\end{tabular}

Nilai W' untuk seluruh alternatif berdasarkan K1 dijumlahkan sebagai pembagi nilai $W$ ' dari setiap alternatif untuk mendapatkan nilai normalisasi nilai bobot vektor fuzzy (W) yang merupakan nilai prioritas alternatif berdasarkan K1 sebagai berikut:

Tabel 13. Prioritas Alternatif dari K1

\begin{tabular}{|l|c|c|c|}
\hline $\mathrm{W}=$ & 0.33333 & 0.33333 & 0.33333 \\
\hline & $\mathrm{A}$ & $\mathrm{B}$ & $\mathrm{C}$ \\
\hline
\end{tabular}

Prioritas alternatif berdasarkan K1 dapat digambarkan dalam grafik sebagai berikut:

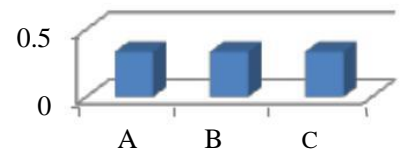

Gambar 1. Prioritas Alternatif dari K1

Sedangkan untuk mencari nilai prioritas alternatif berdasarkan $\mathrm{K} 2$ dengan nilai tingkat kepentingan sebagai berikut: 


\begin{tabular}{|c|c|}
\hline ID KYW & NILAI K2 \\
\hline A & 6 \\
\hline B & 8 \\
\hline C & 7 \\
\hline
\end{tabular}

Dengan proses yang sama dengan perbandingan alternatif berdasarkan $\mathrm{K} 1$, maka langkah berikutnya yaitu dilakukan perbandingan antar alternatif berdasarkan K2 dengan sifat metode AHP yaitu reciprocal dengan hasil sebagai berikut:

Tabel 15. Nilai Tingkat Kepentingan Antar

\begin{tabular}{|c|c|c|c|}
\hline \multicolumn{4}{|c|}{ Alternatif dari $\mathrm{K} 2$} \\
\hline K2 & A & B & C \\
\hline $\mathbf{A}$ & 10. & 330.5 & \\
\hline B & 3 & 1 & 2 \\
\hline $\mathrm{C}$ & 2 & 0.5 & 1 \\
\hline
\end{tabular}

Selanjutnya nilai tersebut dikonversi menggunakan skala fuzzy sesuai tabel 8 , sebagai berikut:

Tabel 16. Mengkonversi Skala AHP ke Skala Fuzzy Setiap Alternatif dari K2

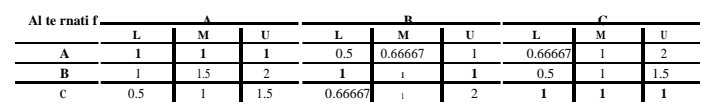

Setelah didapatkan nilai tersebut di atas, maka setiap baris dijumlahkan, berikutnya hasil jumlah baris digunakan mencari nilai jumlah kolom, yang dapat digunakan untuk menghitung nilai sintesis fuzzy (Si) sebagai berikut:

Tabel 17. Nilai Sintesis Fuzzy (Si) Alternatif dari K2

\begin{tabular}{|c|c|c|c|}
\hline \multirow{2}{*}{ Al te rnati f } & \multicolumn{3}{|c|}{ Si } \\
\cline { 2 - 4 } & $\mathbf{L}$ & $\mathbf{M}$ & $\mathbf{U}$ \\
\hline $\mathbf{A}$ & 0.16667 & .29091 & 0.55537 \\
\hline B & 0.19231 & .38182 & 0.65854 \\
\hline C0.16667 & 0.32727 & 0.65854 & \\
\hline
\end{tabular}

Dari hasil tersebut di atas, dilakukan perhitungan nilai vektor fuzzy AHP (v) dan nilai ordinat defuzzifikasi (d') hingga didapatkan nilai bobot vektor fuzzy (W') sebagai berikut:

Tabel 18. Bobot Vektor Fuzzy (W') Alternatif dari K2

\begin{tabular}{|l|c|c|c|}
\hline $\mathrm{W}^{\prime}=$ & 0.04924 & 0.04602 & 0 \\
\hline & $\mathrm{A}$ & $\mathrm{B}$ & $\mathrm{C}$ \\
\hline
\end{tabular}

Nilai W' untuk seluruh alternatif berdasarkan K2 dijumlahkan sebagai pembagi nilai W' dari setiap alternatif untuk mendapatkan nilai normalisasi nilai bobot vektor fuzzy (W) yang merupakan nilai prioritas alternatif berdasarkan K2 sebagai berikut:

Tabel 19. Prioritas Alternatif dari K2

\begin{tabular}{|l|c|c|c|}
\hline $\mathrm{W}=$ & 0.51687 & $0.4831 \beta$ & 0 \\
\hline & $\mathrm{A}$ & $\mathrm{B}$ & $\mathrm{C}$ \\
\hline
\end{tabular}

Prioritas alternatif berdasarkan K2 dapat digambarkan dalam grafik sebagai berikut:

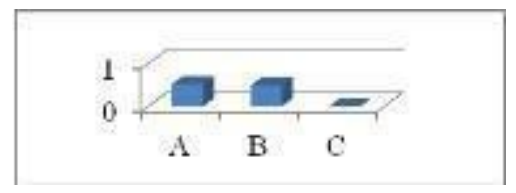

Gambar 2. Prioritas Alternatif dari K2

Untuk mencari nilai prioritas alternatif berdasarkan $\mathrm{K} 3$ dengan nilai tingkat kepentingan sebagai berikut:

Tabel 20. Nilai Alternatif dari K3
\begin{tabular}{|c|c|}
\hline ID KYW & NILAI K3 \\
\hline A & 8 \\
\hline B & 7 \\
\hline C & 7 \\
\hline
\end{tabular}

Dengan proses yang sama dengan perbandingan alternatif berdasarkan $\mathrm{K} 2$, maka langkah berikutnya yaitu dilakukan perbandingan antar alternatif berdasarkan $\mathrm{K} 3$ dengan sifat metode AHP yaitu reciprocal dengan hasil sebagai berikut:

Tabel 21. Nilai Tingkat Kepentingan Antar Alternatif dari K3

\begin{tabular}{|cc|c|c|c|}
\hline K3 & & A & B & C \\
\hline A & $\mathbf{1}$ & 2 & 2 \\
\hline B & 0.5 & $\mathbf{1}$ & 1 \\
\hline C & 0.5 & 1 & $\mathbf{1}$ \\
\hline
\end{tabular}

Selanjutnya nilai tersebut dikonversi menggunakan skala fuzzy sesuai tabel 8 , sebagai berikut:

Tabel 22. Mengkonversi Skala AHP ke Skala Fuzzy Setiap Alternatif dari K3

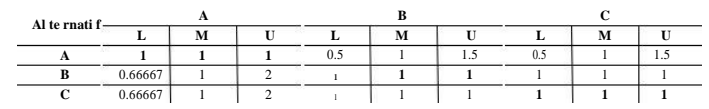

Setelah didapatkan nilai tersebut di atas, maka setiap baris dijumlahkan, berikutnya hasil jumlah baris digunakan mencari nilai jumlah kolom, yang dapat digunakan untuk menghitung nilai sintesis fuzzy (Si) sebagai berikut:

\begin{tabular}{|c|c|c|c|}
\hline \multirow{2}{*}{ Al te rnati f } & \multicolumn{3}{|c|}{ Si } \\
\hline & $\mathbf{L}$ & M & $\mathbf{U}$ \\
\hline $\mathbf{A}$ & 0.166670 & .333330 .5 & 4545 \\
\hline B & 0.222220 & 333330.54 & 545 \\
\hline $\mathrm{C} 0.22$ & 20.333330 & .54545 & \\
\hline
\end{tabular}

Dari hasil tersebut di atas, dilakukan perhitungan nilai vektor fuzzy AHP (v) dan nilai ordinat defuzzifikasi (d') hingga didapatkan nilai bobot vektor fuzzy (W') sebagai berikut:

Tabel 24. Bobot Vektor Fuzzy (W') Alternatif dari K3

\begin{tabular}{|l|l|l|l|}
\hline $\mathrm{W}^{\prime}=$ & 1 & 1 & 1 \\
\hline & $\mathrm{A}$ & $\mathrm{B}$ & $\mathrm{C}$ \\
\hline
\end{tabular}


Nilai W' untuk seluruh alternatif berdasarkan K3 dijumlahkan sebagai pembagi nilai W' dari setiap alternatif untuk mendapatkan nilai normalisasi nilai bobot vektor fuzzy (W) yang merupakan nilai prioritas alternatif berdasarkan $\mathrm{K} 3$ sebagai berikut:

Tabel 25. Prioritas Alternatif dari K3

\begin{tabular}{|l|c|c|c|}
\hline $\mathrm{W}=$ & 0.33333 & 0.33333 & 0.33333 \\
\hline & $\mathrm{A}$ & $\mathrm{B}$ & $\mathrm{C}$ \\
\hline
\end{tabular}

Prioritas alternatif berdasarkan K3 dapat digambarkan dalam grafik sebagai berikut:

\section{5}

0

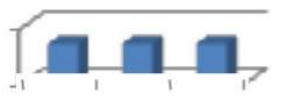

A BC

Gambar 3. Prioritas Alternatif dari K3

Untuk mencari nilai prioritas alternatif berdasarkan K4 dengan nilai tingkat kepentingan sebagai berikut:

Tabel 26. Nilai Alternatif dari K4

\begin{tabular}{|c|c|}
\hline ID KYW & NILAI K4 \\
\hline A & 6 \\
\hline B & 9 \\
\hline C & 9 \\
\hline
\end{tabular}

Dengan proses yang sama dengan perbandingan alternatif berdasarkan $\mathrm{K} 3$, maka langkah berikutnya yaitu dilakukan perbandingan antar alternatif berdasarkan K4 dengan sifat metode AHP yaitu reciprocal dengan hasil sebagai berikut:

Tabel 27. Nilai Tingkat Kepentingan Antar Alternatif dari K4

\begin{tabular}{|c|c|c|c|}
\hline K4 & $\mathbf{A}$ & B & $\mathrm{C}$ \\
\hline$\overline{\mathbf{A}}$ & 1 & 0.25 & 0.25 \\
\hline B & 4 & 1 & 1 \\
\hline $\mathrm{C}$ & 4 & 1 & 1 \\
\hline
\end{tabular}

Selanjutnya nilai tersebut dikonversi menggunakan skala fuzzy sesuai tabel 8, sebagai berikut:

Tabel 28. Mengkonversi Skala AHP ke Skala Fuzzy Setiap Alternatif dari K4

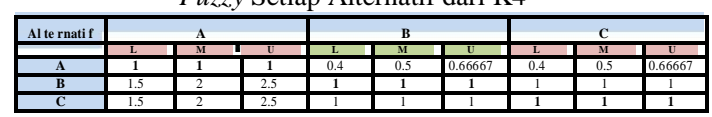

Setelah didapatkan nilai tersebut di atas, maka setiap baris dijumlahkan, berikutnya hasil jumlah baris digunakan mencari nilai jumlah kolom, yang dapat digunakan untuk menghitung nilai sintesis fuzzy (Si) sebagai berikut:

Tabel 29. Nilai Sintesis Fuzzy (Si) Alternatif dari K4

\begin{tabular}{|c|c|c|c|}
\hline \multirow{2}{*}{ Al te rnati f } & \multicolumn{3}{|c|}{$\mathbf{S i}$} \\
\cline { 2 - 4 } & $\mathbf{L}$ & $\mathbf{M}$ & $\mathbf{U}$ \\
\hline $\mathbf{A}$ & 0.15882 & 0.2 & 0.26515 \\
\hline B & 0.30882 & 0.4 & 0.51136 \\
\hline C & 0.308820 & .40 .51136 & \\
\hline
\end{tabular}

Dari hasil tersebut di atas, dilakukan perhitungan nilai vektor fuzzy AHP (v) dan nilai ordinat defuzzifikasi (d') hingga didapatkan nilai bobot vektor fuzzy (W') sebagai berikut:

Tabel 30. Bobot Vektor Fuzzy (W') Alternatif dari K4

\begin{tabular}{|l|l|l|l|}
\hline $\mathrm{W}^{\prime}=$ & 1 & 0 & 0 \\
\hline & $\mathrm{A}$ & $\mathrm{B}$ & $\mathrm{C}$ \\
\hline
\end{tabular}

Nilai W' untuk seluruh alternatif berdasarkan $\mathrm{K} 4$ dijumlahkan sebagai pembagi nilai $W^{\prime}$ dari setiap alternatif untuk mendapatkan nilai normalisasi nilai bobot vektor fuzzy (W) yang merupakan nilai prioritas alternatif berdasarkan K4 sebagai berikut:

Tabel 31. Prioritas Alternatif dari K4

\begin{tabular}{|l|l|l|l|}
\hline $\mathrm{W}=$ & 1 & 0 & 0 \\
\hline & $\mathrm{A}$ & $\mathrm{B}$ & $\mathrm{C}$ \\
\hline
\end{tabular}

Prioritas alternatif berdasarkan K4 dapat digambarkan dalam grafik sebagai berikut:

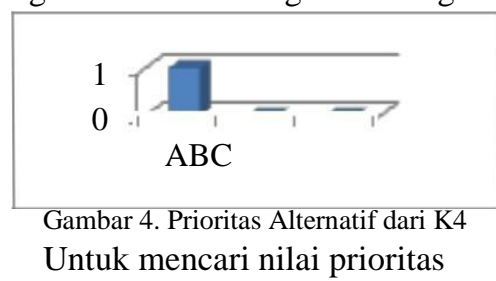

alternatif berdasarkan K5 dengan nilai tingkat kepentingan sebagai berikut:

Tabel 32. Nilai Alternatif dari K5

\begin{tabular}{|c|c|}
\hline ID KYW & NILAI K5 \\
\hline $\mathrm{A}$ & 7 \\
\hline $\mathrm{B}$ & 7 \\
\hline $\mathrm{C}$ & 7 \\
\hline
\end{tabular}

Dengan proses yang sama dengan perbandingan alternatif berdasarkan K4, maka langkah berikutnya yaitu dilakukan perbandingan antar alternatif berdasarkan K5 dengan sifat metode AHP yaitu reciprocal dengan hasil sebagai berikut:

Tabel 33. Nilai Tingkat Kepentingan Antar Alternatif dari K5

\begin{tabular}{|c|c|c|c|}
\hline K5 & A & B & C \\
\hline A & $\mathbf{1}$ & 1 & 1 \\
\hline B & 1 & $\mathbf{1}$ & 1 \\
\hline C & 1 & 1 & $\mathbf{1}$ \\
\hline
\end{tabular}

Selanjutnya nilai tersebut dikonversi menggunakan skala fuzzy sesuai tabel 8 , sebagai berikut:

Tabel 34. Mengkonversi Skala AHP ke Skala Fuzzy Setiap Alternatif dari K5 


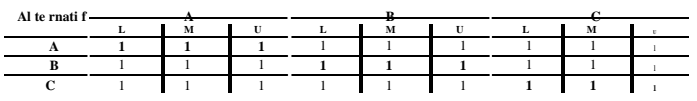

Setelah didapatkan nilai tersebut di atas, maka setiap baris dijumlahkan, berikutnya hasil jumlah baris digunakan mencari nilai jumlah kolom, yang dapat digunakan untuk menghitung nilai sintesis fuzzy (Si) sebagai berikut:

\begin{tabular}{|c|c|c|c|}
\hline \multirow{2}{*}{ Al te rnati f } & \multicolumn{3}{|c|}{ Si } \\
\hline & $\mathbf{L}$ & M & $\mathbf{U}$ \\
\hline $\mathbf{A}$ & 0.333330 & $33333 \quad 0.33$ & 333 \\
\hline B & 0.333330 & 333330.333 & 33 \\
\hline $\mathrm{C} 0.33$ & 0.333330 & 33333 & \\
\hline
\end{tabular}

Dari hasil tersebut di atas, dilakukan perhitungan nilai vektor fuzzy AHP (v) dan nilai ordinat defuzzifikasi (d') hingga didapatkan nilai bobot vektor fuzzy (W') sebagai berikut:

Tabel 36. Bobot Vektor Fuzzy (W') Alternatif dari K5

\begin{tabular}{|l|l|l|l|}
\hline $\mathrm{W}^{\prime}=$ & 1 & 1 & 1 \\
\hline & $\mathrm{A}$ & $\mathrm{B}$ & $\mathrm{C}$ \\
\hline
\end{tabular}

Nilai W' untuk seluruh alternatif berdasarkan K5 dijumlahkan sebagai pembagi nilai W' dari setiap alternatif untuk mendapatkan nilai normalisasi nilai bobot vektor fuzzy (W) yang merupakan nilai prioritas alternatif berdasarkan K5 sebagai berikut:

Tabel 37. Prioritas Alternatif dari K5

\begin{tabular}{|l|c|c|c|}
\hline $\mathrm{W}=$ & 0.33333 & 0.33333 & 0.33333 \\
\hline & $\mathrm{A}$ & $\mathrm{B}$ & $\mathrm{C}$ \\
\hline
\end{tabular}

Prioritas alternatif berdasarkan K5

dapat digambarkan dalam grafik sebagai berikut:

0.5

0

$$
\text { A } \mathrm{BC}
$$

Gambar 5. Prioritas Alternatif dari K5

Untuk mencari nilai prioritas alternatif berdasarkan K6 dengan nilai tingkat kepentingan sebagai berikut:

Tabel 38. Nilai Alternatif dari K6

\begin{tabular}{|c|c|}
\hline ID KYW & NILAI K6 \\
\hline A & 7 \\
\hline B & 5 \\
\hline C & 9 \\
\hline
\end{tabular}

Dengan proses yang sama dengan perbandingan alternatif berdasarkan K5, maka langkah berikutnya yaitu dilakukan perbandingan antar alternatif berdasarkan K6 dengan sifat metode AHP yaitu reciprocal dengan hasil sebagai berikut:

Tabel 39. Nilai Tingkat Kepentingan Antar Alternatif dari K6

\begin{tabular}{|c|c|c|c|}
\hline K6 & A & B & C \\
\hline A & $\mathbf{1}$ & 3 & 0.33333 \\
\hline B & 0.33333 & $\mathbf{1}$ & 0.2 \\
\hline C & 3 & 5 & $\mathbf{1}$ \\
\hline
\end{tabular}

Selanjutnya nilai tersebut dikonversi menggunakan skala fuzzy sesuai tabel 8 , sebagai berikut:

Tabel 40. Mengkonversi Skala AHP ke Skala Fuzzy Setiap Alternatif dari K6

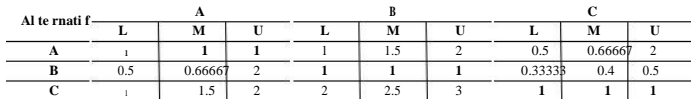

Setelah didapatkan nilai tersebut di atas, maka setiap baris dijumlahkan, berikutnya hasil jumlah baris digunakan mencari nilai jumlah kolom, yang dapat digunakan untuk menghitung nilai sintesis fuzzy (Si) sebagai berikut:

Tabel 41. Nilai Sintesis Fuzzy (Si) Alternatif dari K6

\begin{tabular}{|c|c|c|c|}
\hline \multirow{2}{*}{ Al te rnati f } & \multicolumn{3}{|c|}{ Si } \\
\cline { 2 - 4 } & $\mathbf{L}$ & $\mathbf{M}$ & $\mathbf{U}$ \\
\hline $\mathbf{A}$ & 0.17241 & 0.30945 & 0.6 \\
\hline B & 0.12644 & 0.20195 & 0.42 \\
\hline C & 0.275860 .48860 .72 & \\
\hline
\end{tabular}

Dari hasil tersebut di atas, dilakukan perhitungan nilai vektor fuzzy AHP (v) dan nilai ordinat defuzzifikasi (d') hingga didapatkan nilai bobot vektor fuzzy (W') sebagai berikut:

Tabel 42. Bobot Vektor Fuzzy (W') Alternatif dari K6

\begin{tabular}{|l|c|c|c|}
\hline $\mathrm{W}^{\prime}=$ & 0.12948 & 1 & 0.16597 \\
\hline & $\mathrm{A}$ & $\mathrm{B}$ & $\mathrm{C}$ \\
\hline
\end{tabular}

Nilai W' untuk seluruh alternatif berdasarkan K6 dijumlahkan sebagai pembagi nilai W' dari setiap alternatif untuk mendapatkan nilai normalisasi nilai bobot vektor fuzzy (W) yang merupakan nilai prioritas alternatif berdasarkan K6 sebagai berikut:

Tabel 43. Prioritas Alternatif dari K6

\begin{tabular}{|l|c|c|c|}
\hline $\mathrm{W}=$ & 0.09995 & 0.77193 & 0.12812 \\
\hline & $\mathrm{A}$ & $\mathrm{B}$ & $\mathrm{C}$ \\
\hline
\end{tabular}

Prioritas alternatif berdasarkan K6 dapat digambarkan dalam grafik sebagai berikut:

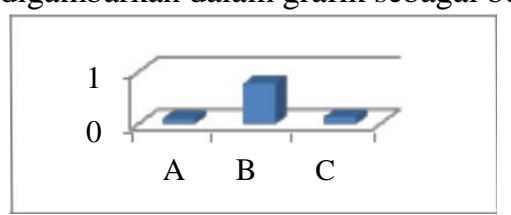

Gambar 6. Prioritas Alternatif dari K6

Untuk mencari nilai prioritas alternatif berdasarkan K7 dengan nilai tingkat kepentingan sebagai berikut:

Tabel 44. Nilai Alternatif dari K7 


\begin{tabular}{|c|c|}
\hline ID KYW & NILAI K7 \\
\hline $\mathrm{A}$ & 6 \\
\hline $\mathrm{B}$ & 8 \\
\hline $\mathrm{C}$ & 6 \\
\hline
\end{tabular}

Dengan proses yang sama dengan perbandingan alternatif berdasarkan K6, maka langkah berikutnya yaitu dilakukan perbandingan antar alternatif berdasarkan K7 dengan sifat metode AHP yaitu reciprocal dengan hasil sebagai berikut:

Tabel 45. Nilai Tingkat Kepentingan Antar Alternatif dari K7

\begin{tabular}{|c|c|c|c|}
\hline K7 & A & B & C \\
\hline A & $\mathbf{1}$ & 0.33333 & 1 \\
\hline B & 3 & $\mathbf{1}$ & 3 \\
\hline C & 1 & 0.33333 & $\mathbf{1}$ \\
\hline
\end{tabular}

Selanjutnya nilai tersebut dikonversi menggunakan skala fuzzy sesuai tabel 8 , sebagai berikut:

Tabel 46. Mengkonversi Skala AHP ke Skala Fuzzy Setiap Alternatif dari K7

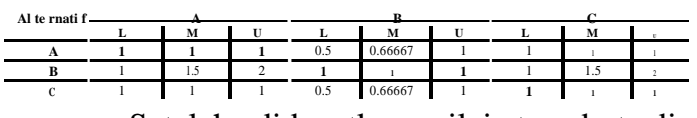

Setelah didapatkan nilai tersebut di atas, maka setiap baris dijumlahkan, berikutnya hasil jumlah baris digunakan mencari nilai jumlah kolom, yang dapat digunakan untuk menghitung nilai sintesis fuzzy (Si) sebagai berikut:

Tabel 47. Nilai Sintesis Fuzzy (Si) Alternatif dari K7

\begin{tabular}{|c|c|c|c|}
\hline \multirow{2}{*}{ Al te rnati f f } & \multicolumn{3}{|c|}{ Si } \\
\cline { 2 - 4 } & $\mathbf{L}$ & $\mathbf{M}$ & $\mathbf{U}$ \\
\hline A & 0.22727 & 0.28571 & 0.375 \\
\hline B & 0.27273 & 0.42857 & 0.625 \\
\hline C & 0.22727 & 0.28571 & 0.375 \\
\hline
\end{tabular}

Dari hasil tersebut di atas, dilakukan perhitungan nilai vektor fuzzy AHP (v) dan nilai ordinat defuzzifikasi (d') hingga didapatkan nilai bobot vektor fuzzy (W') sebagai berikut:

Tabel 48. Bobot Vektor Fuzzy (W') Alternatif dari K7

\begin{tabular}{|l|c|c|c|}
\hline $\mathrm{W}^{\prime}=$ & 0.18543 & 0.0918 & 1 \\
\hline & $\mathrm{A}$ & $\mathrm{B}$ & $\mathrm{C}$ \\
\hline
\end{tabular}

Nilai W' untuk seluruh alternatif berdasarkan K7 dijumlahkan sebagai pembagi nilai W' dari setiap alternatif untuk mendapatkan nilai normalisasi nilai bobot vektor $f u z z y(\mathrm{~W})$ yang merupakan nilai prioritas alternatif berdasarkan $\mathrm{K} 7$ sebagai berikut:

Tabel 49. Prioritas Alternatif dari K7

\begin{tabular}{|l|c|c|c|}
\hline $\mathrm{W}=$ & 0.14518 & 0.07188 & 0.78294 \\
\hline & A & B & C \\
\hline
\end{tabular}

Prioritas alternatif berdasarkan K7

dapat digambarkan dalam grafik sebagai berikut:

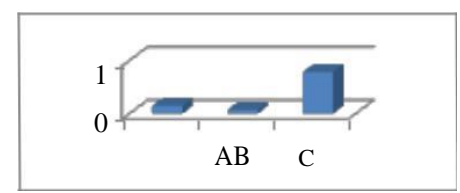

Gambar 7. Prioritas Alternatif dari K7

Untuk mencari nilai prioritas

alternatif berdasarkan $\mathrm{K} 8$ dengan nilai tingkat kepentingan sebagai berikut:

Tabel 50. Nilai Alternatif dari K8

\begin{tabular}{|c|c|}
\hline ID KYW & NILAI K8 \\
\hline A & 8 \\
\hline B & 8 \\
\hline C & 9 \\
\hline
\end{tabular}

Dengan proses yang sama dengan perbandingan alternatif berdasarkan $\mathrm{K} 7$, maka langkah berikutnya yaitu dilakukan perbandingan antar alternatif berdasarkan K8 dengan sifat metode AHP yaitu reciprocal dengan hasil sebagai berikut:

Tabel 51. Nilai Tingkat Kepentingan Antar

\begin{tabular}{|c|c|c|c|}
\multicolumn{5}{|c}{ Alternatif dari K8 } \\
\hline K8 & A & B & C \\
\hline A & $\mathbf{1}$ & 1 & 0.5 \\
\hline B & 1 & $\mathbf{1}$ & 0.5 \\
\hline C & 2 & 2 & 1 \\
\hline
\end{tabular}

Selanjutnya nilai tersebut dikonversi menggunakan skala fuzzy sesuai tabel 8 , sebagai berikut:

Tabel 52. Mengkonversi Skala AHP ke Skala Fuzzy Setiap Alternatif dari $\mathrm{K} 8$

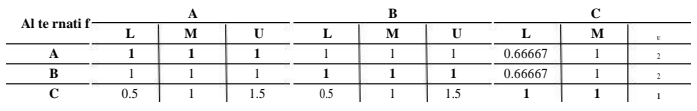

Setelah didapatkan nilai tersebut di atas, maka setiap baris dijumlahkan, berikutnya hasil jumlah baris digunakan mencari nilai jumlah kolom, yang dapat digunakan untuk menghitung nilai sintesis fuzzy (Si) sebagai berikut:

\begin{tabular}{|c|c|c|c|}
\hline \multirow{2}{*}{ Al te rnati f } & \multicolumn{3}{|c|}{$\mathbf{S i}$} \\
\hline & $\mathbf{L}$ & M & $\mathbf{U}$ \\
\hline $\mathbf{A}$ & 0.22222 & .333330 .5 & 4545 \\
\hline B & 0.222220 & 333330.54 & 545 \\
\hline $\mathrm{C} 0.16$ & 70.333330 & .54545 & \\
\hline
\end{tabular}

Dari hasil tersebut di atas, dilakukan perhitungan nilai vektor fuzzy AHP (v) dan nilai ordinat defuzzifikasi (d') hingga didapatkan nilai bobot vektor fuzzy (W') sebagai berikut:

Tabel 53. Bobot Vektor Fuzzy (W') Alternatif dari K8

\begin{tabular}{|l|l|l|l|}
\hline $\mathrm{W}^{\prime}=$ & 1 & 1 & 1 \\
\hline & $\mathrm{A}$ & $\mathrm{B}$ & $\mathrm{C}$ \\
\hline
\end{tabular}

Nilai W' untuk seluruh alternatif berdasarkan K8 dijumlahkan sebagai pembagi nilai W' dari setiap alternatif untuk mendapatkan nilai normalisasi nilai bobot 
vektor fuzzy (W) yang merupakan nilai prioritas alternatif berdasarkan $\mathrm{K} 8$ sebagai berikut:

Tabel 53. Prioritas Alternatif dari K8

\begin{tabular}{|c|c|c|c|}
\hline $\mathrm{W}=$ & 0.33333 & 0.33333 & 0.33333 \\
\hline & $\mathrm{A}$ & $\mathrm{B}$ & $\mathrm{C}$ \\
\hline
\end{tabular}

Prioritas alternatif berdasarkan K8 dapat digambarkan dalam grafik sebagai berikut:

0.5

0

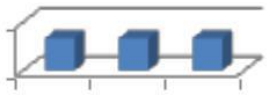

A B C

Gambar 8. Prioritas Alternatif dari K8

Untuk mendapatkan nilai prioritas alternatif berdasarkan K9 sampai dengan K14 memiliki langkah yang sama dengan prioritas alternatif K1 sampai dengan K8 tersebut di atas. Didapatkan nilai prioritas alternatif berdasarkan K9 sebagai berikut:

Tabel 54. Prioritas Alternatif dari K9

\begin{tabular}{|c|c|c|c|}
\hline $\mathrm{W}=$ & 0.22222 & 0.22222 & 0.55556 \\
\hline & $\mathrm{A}$ & $\mathrm{B}$ & $\mathrm{C}$ \\
\hline
\end{tabular}

Prioritas alternatif berdasarkan K9 dapat digambarkan dalam grafik sebagai berikut:

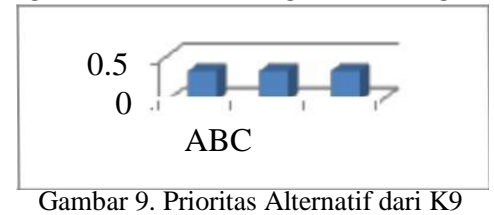

Nilai prioritas alternatif berdasarkan

K10 sebagai berikut:

Tabel 55. Prioritas Alternatif dari K10

\begin{tabular}{|l|c|c|c|}
\hline $\mathrm{W}=$ & 0.56805 & 0.29998 & 0.13197 \\
\hline & $\mathrm{A}$ & $\mathrm{B}$ & $\mathrm{C}$ \\
\hline
\end{tabular}

Prioritas alternatif berdasarkan K10 dapat digambarkan dalam grafik sebagai berikut:

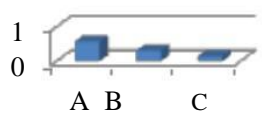

Gambar 10. Prioritas Alternatif dari K10

Nilai prioritas alternatif berdasarkan

K11 sebagai berikut:

Tabel 56. Prioritas Alternatif dari K11

\begin{tabular}{|l|c|c|c|}
\hline $\mathrm{W}=$ & 0.24125 & 0.60311 & 0.15564 \\
\hline & $\mathrm{A}$ & $\mathrm{B}$ & $\mathrm{C}$ \\
\hline
\end{tabular}

Prioritas alternatif berdasarkan K11 dapat digambarkan dalam grafik sebagai berikut:

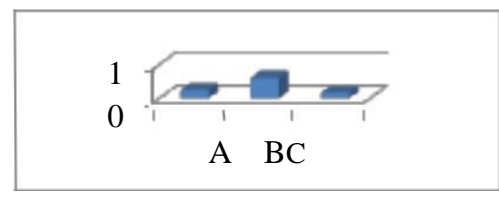

Gambar 11. Prioritas Alternatif dari K11

Nilai prioritas alternatif berdasarkan K12 sebagai berikut:

Tabel 57. Prioritas Alternatif dari K12

\begin{tabular}{|l|c|c|c|}
\hline $\mathrm{W}=$ & 0.33333 & 0.33333 & 0.33333 \\
\hline & $\mathrm{A}$ & $\mathrm{B}$ & $\mathrm{C}$ \\
\hline
\end{tabular}

Prioritas alternatif berdasarkan K12 dapat digambarkan dalam grafik sebagai berikut:

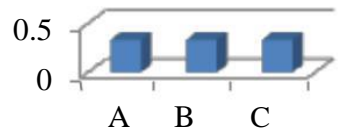

Gambar 12. Prioritas Alternatif dari K12

Nilai prioritas alternatif berdasarkan

K13 sebagai berikut:

Tabel 58. Prioritas Alternatif dari K13

\begin{tabular}{|l|c|c|c|}
\hline $\mathrm{W}=$ & 0.25907 & 0.25907 & 0.48187 \\
\hline & $\mathrm{A}$ & $\mathrm{B}$ & $\mathrm{C}$ \\
\hline
\end{tabular}

Prioritas alternatif berdasarkan K13

dapat digambarkan dalam grafik sebagai berikut:

0.5

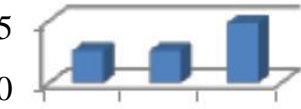

A $\mathrm{B} \quad \mathrm{C}$

Gambar 13. Prioritas Alternatif dari K13

Nilai prioritas alternatif berdasarkan K14 sebagai berikut:

Tabel 59. Prioritas Alternatif dari K14

\begin{tabular}{|l|c|c|c|}
\hline $\mathrm{W}=$ & 0.21147 & 0.77585 & 0.01269 \\
\hline & $\mathrm{A}$ & $\mathrm{B}$ & $\mathrm{C}$ \\
\hline
\end{tabular}

Prioritas alternatif berdasarkan K14 dapat digambarkan dalam grafik sebagai berikut:

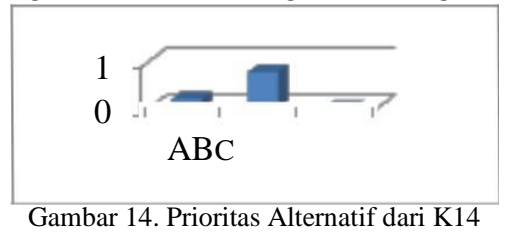

Untuk mendapatkan prioritas global alternatif sebagai hasil akhir keputusan penilaian kinerja karyawan, maka nilai prioritas alternatif dari setiap kriteria yang telah didapatkan pada tahapan di atas dikalikan dengan nilai prioritas kriteria sehingga dihasilkan nilai sebagai berikut:

Tabel 60. Prioritas Global Alternatif 


\begin{tabular}{|c|c|}
\hline & NA \\
\hline $\mathbf{A}$ & 0.25421 \\
\hline $\mathbf{B}$ & 0.29865 \\
\hline $\mathbf{C}$ & 0.44714 \\
\hline
\end{tabular}

Prioritas global alternatif sebagai nilai akhir dapat digambarkan dalam grafik sebagai berikut:

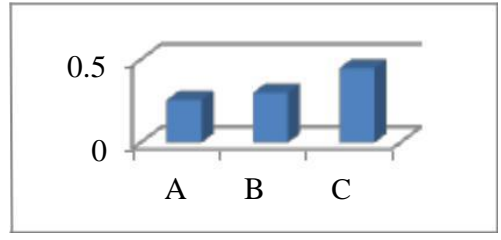

Gambar 15. Prioritas Global Alternatif

Dari hasil prioritas global alternatif didapatkan ranking urutan karyawan yang terbaik, mulai dari karyawan $\mathrm{C}$ dengan nilai 0.45 , berikutnya karyawan B dengan nilai 0.29 , dan yang terakhir 0.25 .

Uji coba dalam sistem ini menggunakan data penilaian karyawan tahun 2016, dan hasilnya jika dibandingkan dengan penilaian dengan proses kalkulasi manual sebelumnya maka akurasi hasilnya signifikan berbeda. Hasil dari penilaian dengan proses kalkulasi manual urutan ranking hasil akhirnya yaitu karyawan $\mathrm{B}$, karyawan $\mathrm{C}$, berikutnya karyawan A. Hal ini membuktikan adanya

ketidaktepatan dalam penilaian kinerja karyawan, karena dengan hasil proses kalkulasi manual tersebut benar adanya terdapat komplain dari karyawan dan meningkatkan kecemburuan sosial antar karyawan. Berikutnya proses penilaian yang manual dengan mengisi form angket kuisioner oleh pimpinan juga membutuhkan waktu yang lama, mulai dari pengisian kuisioner oleh pimpinan divisi hingga kalkulasi nilai akhir yang direkap dan dianalisis oleh HRD, dengan jumlah karyawan yang banyak mulai dari 15 cabang hingga pusat, serta banyaknya kriteria untuk penilaian karyawan. Namun dengan sistem baru yang menerapkan metode fuzzy AHP ini, maka penilaian karyawan lebih efektif.

\section{Kesimpulan dan Saran}

Dari penelitian ini dapat disimpulkan bahwa dengan penerapan metode fuzzy AHP dalam penilaian kinerja karyawan mampu meningkatkan ketepatan sasaran alternatif yang dinilai, dan mampu meningkatkan efektivitas proses penilaian dari awal input nilai primer karyawan hingga kalkulasi nilai akhir.
Adapun saran untuk pengembangan sistem ini yaitu: sistem penilaian kinerja karyawan dapat diintegrasikan dengan sistem keuangan secara otomatis, dan dapat dilakukan pengembangan dengan metode lain.

\section{Daftar Pustaka}

[1] Adnyana, Tjokorda Gde Agung, Gandhiadi, G. K., \& Nilakusmawati, Desak Putu Eka, 2016, Penerapan Metode Fuzzy dalam Penentuan Sektor yang Berpengaruh Terhadap Perekonomian Propinsi Bali, EJurnal Matematika, Vol. 5, No. 2

[2] Afrianty, Iis, 2011, Sistem Pendukung Keputusan (SPK) Pemilihan Karyawan Terbaik Menggunakan Fuzzy AHP, Teknik Informatika, Universitas Islam Negeri Sultan Syarif Kasim, Riau

[3] Ardianto, dkk. 2012. Penerapan Fuzzy Analytical Hierarchy Process pada Sistem Penilaian Kinerja Pegawai di Rumah Sakit Onkologi Surabaya. Jurusan Sistem Informasi. Institut Teknologi Surabaya. Surabaya

[4] Faisol, Ahmad, Muslim, M. Aziz, \& Suyono, Hadi, 2014, Komparasi Fuzzy AHP dengan AHP pada Sistem Pendukung Keputusan Investasi Properti, Jurnal EECCIS, Vol. 8, No. 2

[5] Galus, Muhammad Eka Putra, Nikentari, Nerfita, \& Sallu, Sulfikar, Analisa Penggunaan Metode AHP dan Fuzzy AHP pada Perankingan Siswa, Teknik Informatika, Universitas Maritim Raja Ali Haji, Tanjung Pinang

[6] Igon, Skolastika S., Wisnubhadra, Irya, \& Dwiandiyanta, B. Yudi, 2014, perancangan Sistem Pendukung Keputusan dengan Metode fuzzy AHP dalam Penyeleksian Pemberian

Kredit, Seminar nasional Teknologi Informasi dan komunikasi 2014 (SENTIKA 2014), Yogyakarta

[7] Iskandar, Fauziah Mayasari, Soebroto, Arief Andy, \& Regasari, Rekyan, 2013, Sistem Pendukung Keputusan Seleksi Beasiswa PPA dan BBM Menggunakan Fuzzy AHP, Teknik Informatika, Universitas Brawijaya, Malang

[8] Jasril, Haerani, Elin, \& Afrianty, Iis, 2011, Sistem Pendukung Keputusan (SPK) Pemilihan Karyawan Terbaik Menggunakan Fuzzy AHP, Seminar nasional Aplikasi Teknologi Informasi 2011 (SNATI 2011), Yogyakarta 
[9] Kabir, G. \& Hasin, A. A., 2011, Comparative Analysis of AHP and Fuzzy AHP Models for Multi Criteria Inventory Classification, International Journal of Fuzzy Logic Systems (IJFLS), Volume 1, No. 1

[10] Norhikmah, Rumini, \& Henderi, 2013, metode Fuzzy AHP dan AHP Dalam Penerapan Sistem Pendukung Keputusan, Seminar Nasional Teknologi Informasi dan Multimedia 2013, STIMIK AMIKOM, Yogyakarta

[11] Nur'aini, 2007, Sistem Pendukung Keputusan Investasi Properti, DASI (Data Manajemen Dan Teknologi Informasi

[12] Permana, Sapta Adi, \& Widjajanto, Budi, 2013, Sistem Pendukung Keputusan Berbasis Fuzzy AHP untuk Kelayakan Kredit Rumah, Ilmu Komputer, Universitas dian Nuswantoro, Semarang

[13] Setiyaningsih, Wiji, \& Prasetyo, Amak Yunus Eko, 2017, Konsep Perancangan Sistem Pendukung Keputusan Kinerja Karyawan pada PT. Kimora Surabaya Berbasis Web, Seminar Nasional 2017, Universitas Kanjuruhan, Malang

[14] Setiyaningsih, Wiji, \& Ardian, Yusriel, 2014, Konsep Penilaian Kinerja Tenaga Pendidik dan Edukatif Berdasarkan DP3 Menggunakan AHP, SESINDO 2014, Institut Teknologi Surabaya, Surabaya

[15] Shega, H. N. H., Rahmawati, R. \& Yasin, H., 2012, Penentuan Faktor Prioritas Mahasiswa Dalam Memilih Telepon Seluler Merk Blackberry Dengan Fuzzy $A H P$, Seminar Nasional Ilmu Komputer, Universitas Diponegoro, Semarang

[16] Wahyuni, Sri, \& Hartati, Sri. 2012. Sistem Pendukung Keputusan Model Fuzzy AHP Dalam Pemilihan Kualitas Perdagangan Batu Mulia. Jurnal IJCCS. Vol. 6. No. 1 